\title{
Growth production of the euphausiid Nyctiphanes simplex on the coastal shelf off Bahía Magdalena, Baja California Sur, México
}

\author{
Jaime Gómez-Gutiérrez ${ }^{1, *}$, Roxana De Silva-Dávila ${ }^{1}$, Bertha Lavaniegos-Espejo ${ }^{2, * *}$ \\ 'Centro Interdisciplinario de Ciencias Marinas, Departamento de Plancton y Ecología Marina, Apdo. Postal 592, CP 23000, La Paz, \\ Baja California Sur, México \\ ${ }^{2}$ Centro de Investigaciones Biologicas del Noroeste, km 1 Carr. San Juan de la Costa, Apdo. Postal 128, CP 23000, La Paz, \\ Baja California Sur, México
}

\begin{abstract}
Growth production of the euphausiid Nyctiphanes simplex Hansen was examined off the southwest coast of the peninsula of Baja California, México (Bahia Magdalena, 24 to $25^{\circ} \mathrm{N}$ ), as a function of seasonal changes of temperature, zooplankton biomass, upwelling index, and regional ocean circulation. The data were collected during 4 oceanographic surveys from June to November 1986. High densities of $N$. simplex were found in the shallow coastal waters $(<300 \mathrm{~m})$. High production is maintained during late spring and summer, decreasing during autumn when stratification of the water column develops. We estimate the production attributable to growth of $N$. simplex on the coastal shelf was $273.42 \mathrm{mg} \mathrm{m}^{-2} \mathrm{yr}^{-1}$ and showed a strong seasonal varia. tion. This value was about $1 / 4$ the value previously reported at Bahia Vizcaino in northern Baja California (28 to $29^{\circ} \mathrm{N}$ ). Our data supports the hypothesis that there are strong latitudinal changes in regional production of this species along the west coast of Baja California. The productıon:biomass $(\mathrm{P}: \mathrm{B})$ ratio obtained for the period June to November 1986 was $6.99 \mathrm{yr}^{-1}$. The maximum reproductive activity of $N$. simplex during spring and early summer at Bahía Magdalena appeared to be related to enhancement of the coastal upwelling
\end{abstract}

KEY WORDS: Growth - Production Nyctiphanes simplex Baja Californı

Nyctiphanes simplex Hansen dominates the euphausiid fauna in the nearshore waters of the Pacific coast of Baja California, an area in the transition zone of the California Current and the Eastern Tropical Pacific (Brinton 1960, 1979, Lavaniegos-Espejo 1994, 1995. Gómez-Gutiérrez 1995, 1996, Gómez-Gutiérrez et al. 1995). At times, this species dominates the noncopepod zooplankton in both numbers and biomass, displays a considerable production in coastal upwelling regions, and plays an important role in the trophodynamics of

\footnotetext{
- E-mail: jgomez@vmredipn.ipn.mx

- Present address: Marine Life Research Group, Scripps Institution of Oceanography, University of California, San Diego, La Jolla, California 92093-0227, USA
}

the coastal waters (Olson 1980, Bailey et al. 1982, Gendron 1992, Elorduy \& Caraveo 1994)

Roemmich \& McGowan (1995) reported that zooplankton have declined $80 \%$ from 1951 to 1993, while the surface layer of the ocean has warmed by about $1.5^{\circ} \mathrm{C}$ in southern California. It is not known if these changes caused alterations in the community structure or changes in the dynamics of populations of dominant species. For this reason, it is important to estimate regional production for at least some of the dominant zooplankton species. Recently, Lavaniegos-Espejo (1995) reported production of Nyctiphanes simplex at Bahia Vizcaino in the northern part of the west coast of Baja California ( 28 to $29^{\circ} \mathrm{N}$ ) and found production attributable to growth (Pg) was $1297 \mathrm{mg} \mathrm{m}^{-2} \mathrm{yr}^{-1}$, approximately $75 \%$ of the total (including exuviae $23 \%$ and eggs $2 \%$ ). The population dynamics of $N$. simplex along the southern Pacific coast of Baja California was reported by Gómez-Gutiérrez (1995). An estimation of its production along the southern California Current System has not been attempted. On the coastal shelf off Bahía Magdalena, a clear seasonal change in the population structure of $N$. simplex (Gómez-Gutiérrez 1995) suggests strong seasonal changes in production coupled to regional oceanography. Using a methodology similar to that of Lavaniegos-Espejo (1995), we made a latitudinal comparison of the Pg of $N$. simplex between Bahía Vizcaino and the coastal shelf at Bahia Magdalena. This area features strong seasonal changes in environmental conditions. An intense planktonic drift occurs because of offshore surface transport.

Materials and methods. The euphausiids were collected during 4 oceanographic cruises along the west coast of Baja California during June, August, and November 1986. The sampling grid extended from 24 to $25^{\circ} \mathrm{N}$ covering nighttime samples from 9 stations 


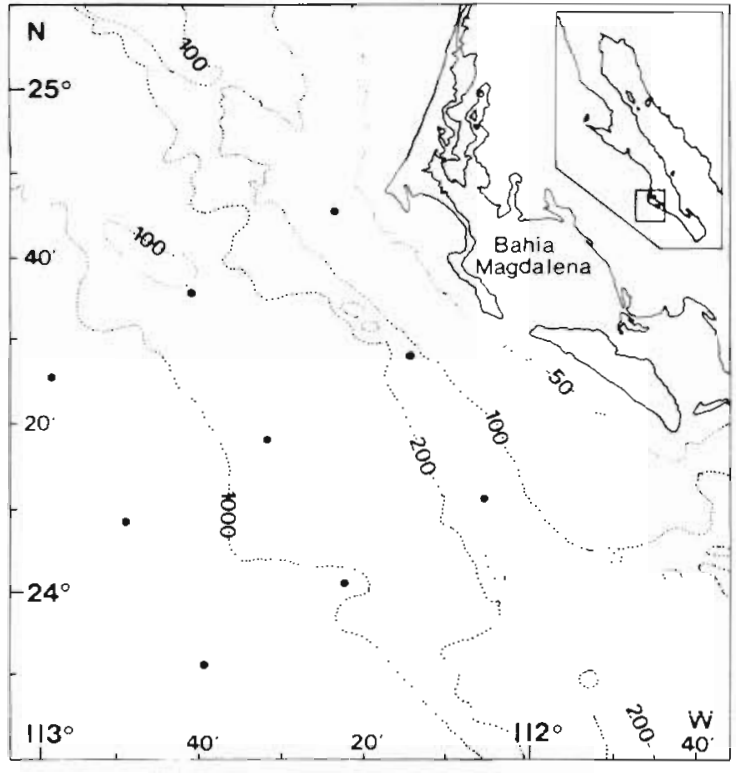

Fig. 1 Coastal shelf of Bahía Magdalena, southwestern Baja California Sur, México, with sampling stations. Isolines are expressed in fathoms

located on the coastal shelf at Bahía Magdalena (Fig. 1). Zooplankton samples were collected at each station using Bongo nets fitted with a flowmeter (General Oceanics) and with 333 and $505 \mu \mathrm{m}$ mesh nets towed obliquely from 10 to $20 \mathrm{~m}$ above the bottom to the surface following the method of Smith \& Richardson (1977). The maximum sampling depth was $210 \mathrm{~m}$. Only samples taken with the $500 \mu \mathrm{m}$ mesh net were used. Except for the first calyptopis stage, all other stages were collected with this net. Large samples were split using a folsom splitter to give 25 or $50 \%$ subsamples depending on the density of euphausiids. The euphausiids collected were identified, counted, and measured (from the posterior of the eye to the end of the telson, not including spines) as calyptopes, furciliae, juveniles, and adults.

To obtain a weight-length relationship, various sized preserved euphausiids were measured, rinsed briefly in distilled water, dried at $60^{\circ} \mathrm{C}$ for $12 \mathrm{~h}$, and weighed with an electrobalance to the nearest $0.0001 \mathrm{mg}$. A weightlength regression equation was obtained for $\mathrm{N} Y \mathrm{C}$ tiphanes simplex using 38 specimens (between 4 and $16 \mathrm{~mm}$ total length) including furciliae, juvenile, male, and female individuals. We used this equation to obtain an estimate of the weight based on the abundance of the euphausiid juveniles and adults per size class using a corrected weight, because of loss of 10 to $17 \%$ by chemical preservation depending on size (Giguere et al. 1989). The relationship between body length $(L)$ in mm and dry weight $(W)$ in $\mathrm{mg}$ we obtained was:

$$
W=0.005371 L^{2316}, \quad r^{2}=0.757
$$

Larvae and adults were grouped into $1 \mathrm{~mm}$ size classes. Production was estimated by applying a model suited to animals with continuous recruitment (Winberg 1971):

$$
\mathrm{Pg}=\sum_{i=1}^{5} \frac{W_{1+1}-W_{1}}{D_{1}} \cdot \bar{N}_{i}
$$

where Pg is daily production due to growth, s is the total number of size classes, $W_{i}$ is weight in the size class $i, W_{1+1}$ is weight in the size class $i+1, N_{1}$ is mean abundance in 1 sampling period in the $i$ th size class, and $D_{1}$ is development time between size classes. Age of the animals was estimated using the parameters of Von Bertalanffy $\left(L_{\text {inf }}=18.6, k=0.010 \mathrm{~d}^{-1}\right)$ for $N y C-$ tiphanes simplex obtained under laboratory conditions by Lavaniegos-Espejo (1992).

Results. Seasonal environmental conditions during the four 1986 oceanographic surveys near Bahia Magdalena were described by Gómez-Gutiérrez (1995, 1996). Seasonal trends in this region can be summa-
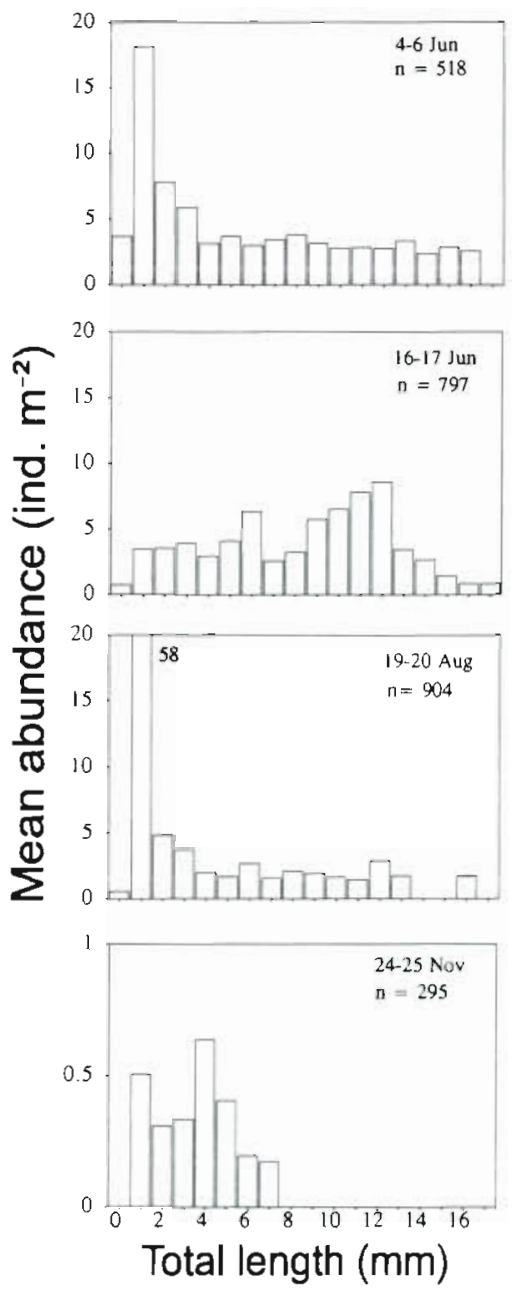

Fig. 2. Length-frequency histograms of Nyctiphanes simplex in samples from Bahía Magdalena $\left(24\right.$ to $25^{\circ} \mathrm{N}$ ) during 1986 
rized as follows: offshore transport (indicated by upwelling index) was found throughout the year, peaking in early summer and autumn; the lowest sea surface temperatures (SST) were recorded from January to June, increasing abruptly (about $6^{\circ} \mathrm{C}$ ) between July and October in spite of significant offshore Ekman transport; SST then began to decrease in November and December (Gómez-Gutiérrez 1995); maximum phytoplankton abundance and zooplankton biomass occurred during late spring and summer, both showing a drastic decrease when warming and stratification of the water column occurred; and zooplankton biomass decreased to about 1/8 from June to November 1986 (Gómez-Gutiérrez 1996).

The size-frequency distribution of Nyctiphanes simplex showed temporal variations throughout the year near Bahía Magdalena (Gómez-Gutiérrez 1995). The average densities (ind. $\mathrm{m}^{-2}$ ) of $N$. simplex for the coastal shelf of Bahía Magdalena generally showed a main mode of larvae and juveniles ( 1 to $3 \mathrm{~mm}$ ) in late spring and summer, indicating intensive reproduction. In November, the abundance of larvae was lower than 1 ind. $\mathrm{m}^{-2}$. The largest adults were found in late June $(17 \mathrm{~mm})$. The size group between 8 and $17 \mathrm{~mm}$ disappeared during November 1986 (Fig. 2). In this study, animals between 15 and $17 \mathrm{~mm}$ total length contributed significantly to the biomass from June to August 1986. Individuals of this size range were not found by Lavaniegos-Espejo (1995) at Bahía Vizcaíno. Barange \& Boyd (1992) found unusual high concentration of large individuals of Nyctiphanes capensis
(>21 $\mathrm{mm}$ total length) over the shelf of the northern Benguela upwelling system (central Namibia 22 to $23^{\circ} \mathrm{S}$ ) (warmer compared with southern regions). They can be responsible for a great part of the biomass contributed by this species in this area. These authors suggested that unusually large individuals may be produced as a response to advantageous environmental conditions of central Namibia. In our work large individuals were recorded during June when presumably there were favorable environment conditions.

Since females produce multiple broods, larval release in Nyctiphanes simplex is continuous over much of the year and the species has a relatively short life span ( 7 to 9 mo) (Lavaniegos-Espejo 1992, GómezGutiérrez 1995). For our work, we used a model suited to animals with continuous recruitment (Winberg 1971). The 2 values for Pg obtained in June ( 4 to 8 and 16 to 17) were considered as replicates and production (P) and biomass (B) of both oceanographic surveys were averaged. Thus, the mean Pg was $0.7491 \mathrm{mg} \mathrm{m}^{-2}$ $\mathrm{d}^{-1}$ or $273.42 \mathrm{mg} \mathrm{m}^{-2} \mathrm{yr}^{-1}$ (Table 1). A gross estimate of biomass as the average weight of size classes multiplied by mean abundance is $39.12 \mathrm{mg} \mathrm{m}^{-2}$ (Table 2 ). The mean P:B ratio, considering only production attributable to growth, is $6.99 \mathrm{yr}^{-1}$. The $\mathrm{Pg}$ of $N$. simplex was higher during spring and early summer, decreasing to minimum values during November (Table 1). The biomass had a similar trend (Table 2).

Discussion. Production is the sum of growth increments of individuals of 1 population, eggs and molts included, during a period of time (Winberg 1971). Exu-

Table 1 Nyctiphanes simplex on the coastal shelf at Bahia Magdalena (24 to $25^{\circ} \mathrm{N}$ ). Daily production due to growth (Pg) $\left(\mathrm{mg} \mathrm{m} \mathrm{m}^{-2} \mathrm{~d}^{-1}\right)$

\begin{tabular}{|lcccccc|}
\hline Length $(\mathrm{mm})$ & 4 to $8 \mathrm{Jun}$ & 16 to $17 \mathrm{Jun}$ & Mean of June & 19 to 20 Aug & 24 to 25 Nov & Mean \\
\hline $0.1-1$ & 0.0142 & 0.0028 & 0.0085 & 0.0020 & 0.0000 & 0.0035 \\
$1.1-2$ & 0.1291 & 0.0248 & 0.0769 & 0.4020 & 0.0036 & 0.1608 \\
$2.1-3$ & 0.0811 & 0.0368 & 0.0590 & 0.0505 & 0.0032 & 0.0375 \\
$3.1-4$ & 0.0798 & 0.0536 & 0.0667 & 0.0505 & 0.0045 & 0.0406 \\
$4.1-5$ & 0.0521 & 0.0483 & 0.0502 & 0.0327 & 0.0104 & 0.0311 \\
$5.1-6$ & 0.0700 & 0.0786 & 0.0743 & 0.0318 & 0.0078 & 0.0380 \\
$6.1-7$ & 0.0636 & 0.1357 & 0.0996 & 0.0563 & 0.0043 & 0.0534 \\
$7.1-8$ & 0.0796 & 0.0588 & 0.0692 & 0.0371 & 0.0039 & 0.0368 \\
$8.1-9$ & 0.0918 & 0.0787 & 0.0853 & 0.0508 & 0.0000 & 0.0453 \\
$9.1-10$ & 0.0784 & 0.1433 & 0.1108 & 0.0474 & 0.0000 & 0.0528 \\
$10.1-11$ & 0.0701 & 0.1630 & 0.1166 & 0.0413 & 0.0000 & 0.0526 \\
$11.1-12$ & 0.0690 & 0.1917 & 0.1304 & 0.0355 & 0.0000 & 0.0553 \\
$12.1-13$ & 0.0640 & 0.1998 & 0.1319 & 0.0658 & 0.0000 & 0.0659 \\
$13.1-14$ & 0.0709 & 0.0739 & 0.0724 & 0.0363 & 0.0000 & 0.0362 \\
$14.1-15$ & 0.0447 & 0.0496 & 0.0471 & 0.0000 & 0.0000 & 0.0157 \\
$15.1-16$ & 0.0434 & 0.0220 & 0.0327 & 0.0000 & 0.0000 & 0.0109 \\
$16.1-17$ & 0.0286 & 0.0095 & 0.0191 & 0.0188 & 0.0000 & 0.0126 \\
$17.1-18$ & 0.0000 & 0.0000 & 0.0000 & 0.0000 & 0.0000 & 0.0000 \\
Sum & 1.1304 & 1.3708 & 1.2506 & 0.9589 & 0.0377 & 0.7491 \\
Annual & & & & & & 273.42 \\
\hline
\end{tabular}


Table 2. Nyctiphanes simplex on the coastal shelf at Bahía Magdalena (24 to $25^{\circ} \mathrm{N}$ ). Biomass (mg $\mathrm{m}^{-2}$ ) per size class (mm)

\begin{tabular}{|c|c|c|c|c|c|c|}
\hline Length (mm) & 4 to 8 Jun & 16 to 17 Jun & Mean of June & 19 to 20 Aug & 24 to $25 \mathrm{Nov}$ & Mean \\
\hline $0.1-1$ & 0.059 & 0.012 & 0.035 & 0.008 & 0.000 & 0.0146 \\
\hline $1.1-2$ & 0.862 & 0.166 & 0.514 & 2.686 & 0.024 & 1.0746 \\
\hline $2.1-3$ & 0.784 & 0.356 & 0.570 & 0.488 & 0.031 & 0.3630 \\
\hline $3.1-4$ & 1.046 & 0.702 & 0.874 & 0.661 & 0.059 & 0.5314 \\
\hline $4.1-5$ & 0.888 & 0.823 & 0.856 & 0.558 & 0.178 & 0.5305 \\
\hline $5.1-6$ & 1.514 & 1.700 & 1.607 & 0.687 & 0.170 & 0.8211 \\
\hline $6.1-7$ & 1.713 & 3.656 & 2.685 & 1.518 & 0.115 & 1.4392 \\
\hline $7.1-8$ & 2.646 & 1.956 & 2.301 & 1.235 & 0.130 & 1.2222 \\
\hline $8.1-9$ & 3.748 & 3.212 & 3.480 & 2.072 & 0.000 & 1.8506 \\
\hline $9.1-10$ & 3.922 & 7.170 & 5.546 & 2.373 & 0.000 & 2.6397 \\
\hline $10.1-11$ & 4.315 & 10.033 & 7.174 & 2.543 & 0.000 & 3.2389 \\
\hline $11.1-12$ & 5.269 & 14.631 & 9.950 & 2.709 & 0.000 & 4.2199 \\
\hline $12.1-13$ & 6.139 & 19.176 & 12.658 & 6.318 & 0.000 & 6.3251 \\
\hline $13.1-14$ & 8.743 & 9.112 & 8.927 & 4.477 & 0.000 & 4.4681 \\
\hline $14.1-15$ & 7.343 & 8.142 & 7.743 & 0.000 & 0.000 & 2.5810 \\
\hline $15.1-16$ & 10.084 & 5.1 .13 & 7.598 & 0.000 & 0.000 & 2.5328 \\
\hline $16.1-17$ & 10.496 & 3.499 & 6.998 & 6.916 & 0.000 & 4.6380 \\
\hline $17.1-18$ & 0.000 & 3.773 & 1.887 & 0.000 & 0.000 & 0.6289 \\
\hline Sum & 69.573 & 93.232 & 81.403 & 35.249 & 0.706 & 39.1194 \\
\hline
\end{tabular}

Table 3. Comparison of production from growth (Pg), biomass (B), and P:B ratios for some Nyctiphanes species. V variable: NE: not estimated

\begin{tabular}{|c|c|c|c|c|c|}
\hline Species & $\mathrm{Pg}$ & B & $P: B$ & Locality & Source \\
\hline N. couchi ${ }^{\mathrm{a}}$ & $0.67-8.23$ & $0.15-2.07$ & $4.0-5.5(\mathrm{~V})$ & North Atlantic Ocean; North Sea & Lindley (1982a) \\
\hline N. australis & $78.29-84.79$ & $5.39-6.39$ & $13.3-14.5$ & Storm Bay, Tasmania & Ritz \& Hosie (1982) \\
\hline N. capensis $^{\mathrm{b}}$ & $\mathrm{NE}$ & $675.00-5706.00$ & NE & Namibia, Southwest Africa & Barange \& Stuart (1991) \\
\hline N. capensis ${ }^{\mathrm{d}}$ & $\mathrm{NE}$ & $0.40-72.74$ & NE & Algoa Bay, South Africa & Cornew et al. (1992) \\
\hline N. simplex ${ }^{b}$ & 1297.00 & 102.00 & 12.7 & Bahía Vizcaíno, Baja Californja & Lavaniegos-Espejo (1995) \\
\hline N. simplex ${ }^{b}$ & 273.42 & 39.12 & 6.99 & Bahia Magdalena, Baja California & This study \\
\hline \multicolumn{6}{|c|}{$\begin{array}{l}{ }^{4} \mathrm{mg} \mathrm{m}^{-3} \mathrm{yr}^{-1} \text { or } \mathrm{mg} \mathrm{m} \mathrm{m}^{-3} \\
{ }^{\circ} \mathrm{mg} \mathrm{m}^{-2} \mathrm{yr}^{-1} \text { or } \mathrm{mg} \mathrm{m}^{-2}\end{array}$} \\
\hline
\end{tabular}

viae of euphausiids can contribute as much as 7 to 8 times the euphausiid biomass to detrital food webs (Lasker 1966, Ritz \& Hosie 1982, Hosie \& Ritz 1983). In the present study, we estimated only production due to growth. This method was also used by Ritz \& Hosie (1982) for Nyctiphanes australis at Storm Bay, Tasmania, and by Lavaniegos-Espejo (1995) for $N$. simplex at Bahía Vizcaíno, México. According to LavaniegosEspejo (1995), the Pg for N. simplex in Bahía Vizcaino during 1966 contributed about $75 \%$ of the total, while production from exuviae and eggs contributed 23 and $2 \%$ Thus, we estimated the most important proportion of total production for this species.

A comparison of production attributable to growth $(\mathrm{Pg})$, biomass $(\mathrm{B})$, and P:B ratios for Nyctiphanes spp. around the world is shown in Table 3. Comparison between them should be interpreted carefully because these were estimated using different units of volume and area $\left(\mathrm{m}^{-3}\right.$ and $\left.\mathrm{m}^{-2}\right)$ and some of them estimate pro- duction only from growth. It has been demonstrated that the genus Nyctiphanes plays an important role in the trophodynamics of some neritic ecosystems displaying higher $\mathrm{P}: \mathrm{B}$ ratios when compared to other euphausiid genera (Lindley 1982a, b, Ritz \& Hosie 1982). Production of $N$. simplex from growth estimated. in this study was about $1 / 4$ of that estimated for the same species at Bahía Vizcaíno by Lavaniegos-Espejo (1995) because the abundance of larvae, juveniles, and adults was considerably lower on the coastal shelf at Bahía Magdalena during the sampling period. The biomass and $P: B$ ratio were only half that of the northern region. Growth production of this species showed clear latitudinal changes in regional production. Barange \& Boyd (1992) also found strong latitudinal changes in size-frequency distribution of $N$. capensis along the west coast of Africa, suggesting differences in latitudinal production. Mauchline (1980) concluded that euphausiid biomass is greatest at high latitudes. A 
strong seasonality of production and intensity of reproduction was also evident at Bahía Magdalena. We have no information for winter and early spring. In our study, maximum larval production was found during spring and early summer when there is active upwelling (low SST, high phyto- and zooplankton biomass, and a wide mixed layer). The lowest production was found in autumn when the water column becomes stratified (highest SST, lower phyto- and zooplankton biomass). During June 1986, an anomalous high mean nanophytoplankton abundance was found, reaching a concentration of $1.2 \times 10^{6}$ cell $\mathrm{l}^{-1}$, then decreasing to $2.2 \times 10^{4}$ cell $^{-1}$ during November 1986 (A. MartínezLópez \& F. Gómez-Ochoa unpubl. data). According to Lavaniegos-Espejo $(1994,1995)$, this seasonality is less evident in the northern region. There, $N$. simplex showed continuous larval production throughout the year. Most reproduction and the highest values of production were found in fall. Lavaniegos-Espejo (1995) found that, from January to March, a high abundance of individuals $<6 \mathrm{~mm}$ was possible because of migration from other areas. In our study, most reproduction (indicated by calyptopes and ovigerous females) and the highest production at Bahía Magdalena were during late spring and early summer, decreasing to fall. Thus, there was a latitudinal delay of maximum production of this species along the west coast of Baja California.

A comparison of the growth production of $\mathrm{Nycti}_{\text {- }}$ phanes simplex with other Nyctiphanes species shows this species has a production comparable to $N$. australis (Ritz \& Hosie 1982). This could be the combined effect of continuous breeding, a short life span, and warmer temperatures giving a higher turnover rate compared to other euphausiids (see Ritz \& Hosie 1982).

The lower production of Nyctiphanes simplex on the coastal shelf at Bahía Magdalena can be explained because this southern population is influenced by the seasonal northward movement of warmer water during the second part of the year with this population reaching its lowest abundance and production in November (see Gómez-Gutiérrez \& Hernández 1994, Gómez-Gutiérrez 1995, 1996). The southern part of the Baja California peninsula and Gulf of California are the southern limit of the dominance of $N$. simplex (Brinton 1979). The euphausiid community structure south of the Gulf of California is dominated in abundance and biomass by 3 endemic species, Euphausia eximia, E. distinguenda Hansen and E. lamelligera Hansen, and the tropical species E. tenera Hansen (Brinton 1979, Sánchez \& Hendrickx 1984, López 1990. Farber et al. 1994, Gómez-Gutiérrez \& Hernández 1994). These species are tropical and probably have a low production along the southwestern coast of México. In this region, $N$. simplex is less abundant and presumably makes a small contribution to the food web.
Production of Nyctiphanes simplex in the southern part of the California Current has significant latitudinal differences in its seasonality, intensity, and dynamic population compared to northern Baja California. This species contributed a considerable part of the secondary production in these 2 important coastal upwelling regions of Baja California.

Acknowledgements. Thanks to Aída Martínez-López, and to Francisco Gomez-Ochod (CICIMAR-IPN) for allowing us to use their unpublished data on abundance of phytoplankton. Thanks also to Dr Ellis Glazier for editorial assistance on this English language manuscript. This research was supported by funds provided by the Dirección de Estudios de Posgrado e Investigación (DEPI 903361, DEPI 931318) and by the Consejo Nacional de Ciencia y Tecnología (CONACYT D112-904620). J.G.G. is supported by SNI and COFAA-iPN fellowships.

\section{LITERATURE CITED}

Bailey KM, Francis RC, Stevens PR (1982) The life history and fishery of Pacific whiting Merluccius productus Calif Coop Ocean Fish Invest Rep 23:81-98

Barange M, Boyd AJ (1992) Life history, circulation and maintenance of Nyctiphanes capensis (Euphausiacea) in the northern Benguela upwelling system. In: Payne AIL, Brink $\mathrm{KH}$, Hilborn E (eds) Benguela trophic functioning. S Afr J Mar Sci 12:95-106

Barange M. Stuart V (1991) Distribution patterns, abundance and population dynamics of the euphausiids Nyctiphanes capensis and Euphausia hanseni in the northern Benguela upwelling system. Mar Biol 109:93-101

Brinton E (1960) Changes in the distribution of euphausid crustaceans in the region of California Current. Calif Coop Ocean Fish Invest Rep 7:137-146

Brinton E (1979) Parameters relating to the distribution of planktonic organisms, especially euphausiids in the Eastern Tropical Pacific. Prog Oceanogr 8:125-189

Cornew S, Stuart V, Beckley LE (1992) Population structure biomass and distribution of Nyctiphanes capensis (Euphausiacea) in the vicinity of Algoa Bay, South Africa S Afr J Zool 27:14-20

Elorduy GJF, Caraveo PJ (1994) Feeding habits of the ocean whitefish, Caulolatilus princeps Jenyns, 1842 (Pisces: Branchiosterigidae) in La Paz Bay, B.C.S., México. Ciencias Marinas 20:199-218

Farber LJ, Lavin MF, Zapatero MA, Robles JM (1994) Distribution and abundance of euphausiids in the Gulf of Tehuantepec during wind forcing. Deep Sea Res 41: $359-367$

Gendron D (1992) Population structure of daytime surface swarms of Nyctiphanes simplex (Crustacea: Euphausiacea) in the Gulf of California, México. Mar Ecol Prog Ser $87: 1-6$

Giguere LA, St-Pierre JF, Bernier B, Vezina A, Rondeau JG (1989) Can we estimate the true weight of zooplankton samples after chemical preservation? Can J Fish Aquat Sci $46: 522-527$

Gómez-Gutiérrez J (1995) Distribution patterns, abundance and population dynamics of the euphausiids Nyctiphanes simplex and Euphausia eximia off the west coast of Baja California, México. Mar Ecol Prog Ser 119:63-76

Gómez-Gutiérrez J (1996) Ecology of early larval development of Nyctiphanes simplex Hansen (Euphausiacea) off 
the southwest coast of Baja California, Mexico. Bull Mar Sci 58(1):131-146

Gómez-Gutiérrez J. Hernández-Trujillo S (1994) Euphaus1acea and Copepoda of the oceanic front of Cabo San Lucas B.C.S. México, during August 1988. Rev Biol Trop 42(1/2): $153-162$

Gómez-Gutiérrez J, Palomares-García R, Gendron D (1995) Community structure of the euphausiid populations along the west coast of Baja California, México, during the weak ENSO 1986-1987. Mar Ecol Prog Ser 120:41-51

Hosie GW, Ritz DA (1983) Contribution of molting and eggs to secondary production in Nyctiphanes australis (Crustacea: Euphausiacea). Mar Biol 77:215-220

Lasker R (1966) Feeding, growth, respiration and carbon utilization of a euphausiid crustacean. J Fish Res Bd Can 23: $1291-1317$

Lavaniegos-Espejo B (1992) Growth and larval development of Nyctiphanes simplex in laboratory conditions. Calif Coop Ocean Fish Invest Rep 33:152-171

Lavaniegos-Espejo B (1994) Dispersion and development patterns in larvae of Nyctiphanes simplex (Euphausiacea) in the upwelling region off Baja California. Mar Ecol Prog Ser 106:207-225

Lavaniegos-Espejo B (1995) Production of the euphausiid Nyctiphanes simplex in Vizcaino Bay, western Baja California. J Crust Biol 15:444-453

Lindley JA (1982a) Population dynamics and production of euphausiids. III. Meganyctiphanes norvegica and Nyctiphanes couchs in the North Atlantic Ocean and the North

This note was submitted to the editor
Sea. Mar B1ol 66:37-45

Lindley JA (1982b) Continuous plankton records: geographical variations in numerical abundance, biomass and production of euphausiids in the North Atlantıc Ocean and the North Sea. Mar Biol 77:7-10

López CDJ (1990) Distribución de la familia Euphausiidae (Euphausiacea: Crustacea) en el Golfo de Tehuantepec, Mexico. Rev Biol Trop 38:21-28

Mauchline J (1980) The biology of mysids and euphausinds. Adv Mar Biol 18:1-681

Olson RJ (1980) Synopsis of biological data on the southern bluefin tuna Tunnus maccoyii (Castelnau, 1872). Inter-Am Trop Tuna Comm Bull, Spec Rep 2:151-212

Ritz DA, Hosie GW (1982) Production of the puphausiid Nyctiphanes australis in Storm Bay, South-Eastern Tasmania. Mar Biol 68:103-108

Roemmich D, McGowan J (1995) Climatic warming and the decline of zooplankton in the California Current. Science $267: 1324-1326$

Sánchez OL, Hendrickx ME (1984) Resultados de las campañas SIPCO (sur de Sinaloa, México) a bordo del B/O 'El Puma' Abundanria y distribución de los Euphausiacca (Crustacea: Eucarida). An Cent Cienc Mar Limnol Univ Nac Autón Méx 11:99-106

Smith PE, Richardson SL (1977) Standard techniques for pelagic fish and larvae surveys. FAO Fish Tech Pap 175: $1-107$

Winberg GG (1971) Methods for the estimation of production of aquatic animals. Academic Press, London

Manuscript first received: March 6,1996

Revised version accepted: May 17, 1996 